\title{
PENGARUH ENTRENCHMENT EFFECT TERHADAP KUALITAS AUDIT DAN PERAN EFEKTIFITAS KOMITE AUDIT
}

\author{
Herlina Tri Utami \\ Universitas Indonesia \\ e-mail: herlinatriutami@gmail.com \\ Vera Diyanty \\ Universitas Indonesia \\ e-mail: vera.diyanty@ui.ac.id
}

\begin{abstract}
This research aims to investigate the negative entrenchment effect the controlling shareholder to the audit quality and the role of audit committee effectiveness. This study argues that potential agency conflict due to the negative entrenchment effect of controlling shareholder is capable in influencing the selection of public accounting firm between big four, second tier and third tier, that will affect the audit quality. The sample of this research are the manufacturing companies which are listed in the Indonesian stock exchange from 2010 to 2013. This study gives evidence a positive influence between the negative entrenchment effects to the the selection of a high quality public accounting firm. The increasing agency conflict due to the negative entrenchment effect, the probability of selecting a high quality accounting firm is also increasing. In addition, this research also give evidence that the effectiveneness of audit committee can enforce the management to the probability of selecting a high audit quality due to negative entrenchmet effect

Keywords: Entrenchment Effect, Audit committee effectiveness, Corporate Governance, Audit Quality

http://dx.doi.org/10.20885/jaai.vol19.iss2.art5
\end{abstract}

\begin{abstract}
Abstrak
Penelitian ini bertujuan untuk menginvestigasi negative entrenchment effect dari pengawasan shareholder pada kualitas audit dan peran efektifitas komite audit. Penelitian ini berpendapat bahwa potensi konflik keagenan disebabkan oleh negative entrenchment effect dari pengawasan shareholder mampu dalam mempengaruhi pemilihan kantor akuntan publik antara big four, second tier and third tier, yang akan mempengaruhi kualitas audit. Sampel dari penelitian ini yaitu perusahaan manufaktur yang terdaftar dalam Indonesian stock exchange dari tahun 2010- 2013. Penelitian ini memberikan bukti pengaruh positif antara negative entrenchment effect pada pemilihan sebuah kantor akuntan publik yang memiliki kualitas tinggi. Meningkatnya konflik keagenan disebabkan oleh negative entrenchment effect, probabilitas dari pemilihan sebuah kantor akuntan publik yang berkualitas tinggi juga meningkat. Sebagai tambahan, penelitian ini juga memberikan bukti bahwa efektifitas dari komite audit dapat melaksanakan manajemen untuk probabilitas pemilihan sebuah kualitas audit yang tinggi yang disebabkan oleh negative entrenchmet effect.
\end{abstract}

Kata Kunci: Entrenchment Effect, Audit committee effectiveness, Corporate Governance, Audit Quality

\section{PENDAHULUAN}

Berle dan Means (1932) menjelaskan bahwa masalah keagenan antara manajemen dengan pemegang saham terjadi akibat struktur kepemilikan perusahaan yang tersebar di tangan banyak pemegang saham (dispersed ownership). Dalam struktur ini, pemegang saham cenderung tidak mampu untuk melakukan pengawasan yang efektif terhadap tindakan manajemen sehingga kendali perusahaan 
menjadi di tangan manajemen (Shleifer dan Vishny 1986). Umumnya, perusahaan dengan struktur kepemilikan tersebar banyak ditemukan di negara-negara common law dengan perlindungan atas property rights yang kuat, seperti Amerika Serikat, Inggris, Kanada, ataupun Irlandia (Claessens et al.2002).

Tidak seperti negara-negara common law, pada negara-negara yang menganut sistem hukum civil law dengan perlindungan atas property rights yang lemah, mayoritas struktur kepemilikan perusahaannya cenderung terkonsentrasi di tangan segelintir pemegang saham. Claessens dan Fan (2002) menyatakan bahwa ketika struktur kepemilikan perusahaan terkonsentrasi di tangan segelintir pemegang saham pengendali, pemegang saham pengendali tersebut akan memiliki kemampuan untuk mengarahkan berbagai kebijakan perusahaan, atau yang dikenal sebagai entrenchment effect. Adanya entrenchment effect tidak selalu menyebabkan timbulnya konflik keagenan di tubuh perusahaan. Konflik keagenan antara pemegang saham pengendali dan non-pengendali akan terjadi ketika pemegang saham pengendali memilih untuk mengarahkan kebijakan perusahaan sesuai dengan kepentingan pribadinya sehingga menyebabkan pemegang saham non-pengendali tidak mendapatkan apa yang seharusnya menjadi haknya (Claessens dan Fan 2002). Fenomena ini disebut juga sebagai negative entrenchment effect (Claessens dan Fan 2002).

Claessens dan Fan (2002) menyatakan bahwa adanya negative entrenchment effect berpotensi untuk semakin memburuk pada perusahaan yang dikendalikan melalui mekanisme kepemilikan piramida. Hal ini dikarenakan melalui mekanisme kepemilikan piramida pemegang saham pengendali dapat memiliki hak kendali ${ }^{1}$ yang lebih tinggi dibandingkan dengan hak arus kasnya ${ }^{2}$ sehingga pemegang saham pengendali dapat dengan leluasa mengekspropriasi kekayaan perusahaan tanpa harus menanggung biaya yang tinggi bila terjadi kerugian ataupun penurunan nilai perusahaan (Claessens et al. 2000). Untuk menutupi aktivitas ekspropriasinya, pemegang saham pengendali termotivasi untuk menjaga agar pengungkapan laporan keuangannya tetap tidak transparan sehingga ia dapat dengan bebas melakukan tindakan ekspropriasi.

Salah satu cara yang digunakan oleh pemegang saham pengendali untuk menjaga ketidaktransparansian laporan keuangannya adalah dengan menurunkan kualitas pengawasan eksternal dari kantor akuntan publik (Lin dan Liu 2009) dengan cara menunjuk kantor akuntan publik dengan kualitas audit lebih rendah. Choi et al. (2007) dalam penelitiannya membuktikan adanya pengaruh negatif atas entrenchment effect terhadap kualitas audit. Menurut DeAngelo (1981), kualitas audit adalah probabilitas akuntan publik untuk mendeteksi terjadinya pelanggaran pada sistem akuntansi klien (error/fraud) serta melaporkan pelanggaran tersebut.

Di sisi lain, berdasarkan penelitian Fan dan Wong (2005) serta El Ghoul (2007) menemukan bahwa timbulnya potensi konflik keagenan akibat negative entrenchment effect ternyata berpengaruh positif terhadap pemilihan kualitas audit yang diproksikan dengan ukuran kantor akuntan publik. Menurut Fan dan Wong (2005) fenomena tersebut muncul sebagai akibat dari timbulnya motivasi pemegang saham pengendali untuk menghindari risiko peningkatkan cost of capital $^{3}$ yang mehuat perusahaan kesulitan dalam meng akses pendanaan eskternal (Claessens dan Fan 2002).

Terjadinya peningkatan cost of capital akan merugikan pemegang saham pengendali ketika perusahaan dihadapkan pada potensi pertumbuhan yang tinggi (Fan dan Wong 2005). Hal ini dikarenakan ketika terdapat potensi pertumbuhan yang tinggi, adanya kesulitan dalam mengakses pendanaan eskternal akan membuat perusahaan kesulitan dalam mengambil prospek bisnis yang tersedia sehingga pemegang saham pengendali menjadi tidak dapat menikmati hasil dari pertumbuhan operasi bisnisnya (Fan dan Wong 2005; El Goul et al. 2007). Hal ini akan memotivasi pemegang saham pengendali untuk menunjuk kantor akuntan publik yang berkualitas tinggi dalam memberikan assurance atas keandalan 
laporan keuangan perusahaan (Claessens dan Fan, 2002). Penunjukan kantor akuntan publik yang memiliki kualitas audit tinggi terbukti dapat meningkatkan kredibilitas dan keandalan laporan keuangan di mata pemegang saham non-pengendali ataupun investor (Kim et al. 2002; Lennox 1999).

Dalam mekanisme pelaksanaan corporate governance, penunjukkan auditor akan sangat dipengaruhi oleh rekomendasi dari Komite Audit dalam mendukung terciptanya akuntabilitas dan transparansi penyajian laporan keuangan perusahaan (Pedoman Good Corporate Governance Komite Nasional Kebijakan Governance Indonesia). Komite audit yang efektif umumnya beranggotakan atas orang-orang independen dari komunitas bisnis yang memiliki reputasi tinggi sehingga lebih peduli akan adanya risiko kerugian reputasional apabila terjadi kesalahan dalam pelaporan keuangan perusahaan (Abbot dan Parker 2000), Simunic dan Stein (1996) menemukan bahwa komite audit memiliki kemampuan untuk secara langsung mendorong akuntan publik yang telah dikontrak oleh perusahaan untuk meningkatkan ruang lingkup audit sesuai hasil analisis komite audit. Abbott dan Parker (2000) menemukan bahwa perusahaan yang komite auditnya berisikan anggota independen dengan frekuensi rapat dua kali dalam satu tahun cenderung untuk memilih akuntan publik yang berasal dari KAP Big 6.

Penelitian ini bertujuan untuk menginvestigasi pengaruh negative entrenchment effect pemegang saham pengendali terhadap probabilita pemilihan kantor akuntan publik. Penelitian ini mengacu pada penelitian Choi et al. (2007) serta Fan dan Wong (2005) dalam melihat pengaruh negative entrenchment effect pemegang saham pengendali akhir terhadap pemilihan kantor akuntan publik. Adapun pengembangan penelitian yang dilakukan adalah bahwa penelitian ini juga akan menginvestigasi pengaruh keefektifan komite audit dalam memoderasi dampak negative entrenchment effect terhadap probabilita pemilihan kantor akuntan publik.
Penelitian ini penting dilakukan di Indonesia karena lebih dari 50\%, struktur kepemilikan perusahaan terkonsentrsi dan pemegang saham pengendali akhir banyak memiliki hak kendali di atas hak arus kasnya (Diyanty 2012) sehingga potensi adanya negative entrenchment effect cukup tinggi. Potensi dari negative entrenchment effect ini dikhawatirkan akan mempengaruhi kualitas audit. Kualitas laporan keuangan dari suatu kualitas audit yang andal tentunya akan mengurangi konflik keagenan yang terjadi antara pemegang saham pengendali beserta manajemen dan pemegang saham non pengendali.

Dalam penentuan probabilita pemilihan kantor akuntan publik, peneliti akan membandingkan keputusan pemilihan perusahaan terhadap tiga jenis golongan kantor akuntan publik yaitu kantor akuntan publik big four, second tier, dan third tier. Penggolongan kantor akuntan publik akan mengacu kepada pendekatan Soedibyo (2010) yang mengelompokkan kantor akuntan publik berdasarkan ukuran (sizф dari kantor akuntan publik ter sebut.

\section{TINJAUAN PUSTAKA DAN PERUMUSAN HIPOTESIS}

\section{Teori Keagenan dan Struktur Kepemilikan}

Jensen dan Meckling (1976) mendefinisikan hubungan keagenan sebagai sebuah bentuk kontrak antara principal(s) dan agent(s) dimana agent bertanggung jawab untuk memberikan jasa profesionalnya serta membuat keputusan mewakili kepentingan principal. Dalam menjalankan tugasnya, tindakan yang dilakukan agent tidak selamanya searah dengan kepentingan principal. Tindakan oportunis itulah yang kemudian menyebabkan munculnya konflik kepentingan antara agent dengan principal (Berle dan Means 1983). Dalam Struktur kepemilikan yang tersebar yang hampir sebagian besar banyak terdapat pada negara-negara common law seperti Amerika Serikat dan Inggris cenderung memiliki perlindungan investor yang kuat. Sedangkan sebagian besar Negara yang meng- 
anut civil law cenderung memiliki perlindungan investor yang lemah (La Porta 2000). Dengan kondisi perlindungan investor terhadap investor yang lemah, seorang pemegang saham menjadi terinsentif untuk mendapatkan kendali yang lebih besar atas aset atau perusahaannya dengan tujuan untuk melindungi investasinya dari tindakan oportunis manajemen. Hal inilah yang menyebabkan struktuk kepemilikan menjadi terkonsentrasi.

Sebuah perusahaan dikatakan memiliki struktur kepemilikan terkonsentrasi apabila mayoritas kepemilikan perusahaan berada di tangan segelintir pemegang saham yang disebut sebagai pemegang saham pengendali. Terkonsentrasinya kepemilikan kemudian menyebabkan pemegang saham pengendali memiliki kemampuan untuk mengendalikan kebijakan baik atas arah maupun proses operasional perusahaan, hal ini dikenal juga sebagai entrenchment effect (Coffee 2010).

Untuk mendapatkan kendali atas perusahaan, selain melalui akuisisi langsung, Claessens dan Fan (2002) menyatakan bahwa pemegang saham dapat menggunakan dua buah mekanisme lain, yaitu mekanisme kepemilikan piramida (pyramid ownership) serta mekanisme lintas kepemilikan (crossholding). Melalui mekanisme kepemilikan piramida, seorang pemegang saham pengendali memungkinkan untuk dapat memiliki hak kendali yang lebih besar dibandingkan dengan hak arus kas mereka. Hak kendali itu sendiri adalah hak suara untuk ikut serta dalam menentukan kebijakan penting perusahaan ${ }^{4}$. Sementara hak arus kas adalah klaim keuangan pemegang saham terhadap perusahaan ${ }^{5}$ (Claessens et al. 2000).

Entrenchment effect tidak selalu menimbulkan konflik keagenan antara pemegang saham pengendali dan non-pengendali. Konflik keagenan baru akan terjadi ketika pemegang saham pengendali memilih untuk mengarahkan kebijakan perusahaan sesuai dengan kepentingan pribadinya sehingga menyebabkan pemegang saham non-pengendali tidak mendapatkan apa yang seharusnya menjadi haknya. Fenomena ini dikenal juga sebagai negative entrenchment effect.
Claessens dan Fan (2002) menyatakan bahwa, adanya negative entrenchment effect berpotensi untuk semakin memburuk pada perusahaan yang dikendalikan melalui mekanisme kepemilikan piramida. Hal ini dikarenakan melalui mekanisme kepemilikan piramida, pemegang saham pengendali dapat memiliki hak kendali yang lebih tinggi dibandingkan dengan hak arus kasnya, sehingga pemegang saham pengendali dapat dengan leluasa untuk melakukan kegiatan yang tujuannya tidak searah dengan pemegang saham non-pengendali tanpa harus menanggung biaya yang tinggi bila terjadi kerugian ataupun penurunan nilai perusahaan (Claessens et al.2000).

\section{Pengaruh Negative Entrenchment Pemegang Saham Pengendali Akhir Terhadap Proba- bilitas Pemilihan Kantor Akuntan Publik}

Melalui mekanisme kepemilikan piramida pemegang saham pengendali dapat memiliki hak kendali yang lebih tinggi dibandingkan dengan hak arus kasnya (Claessens dan Fan 2002). Hal inilah yang memotivasi pemegang saham pengendali untuk melakukan ekspropriasi yang merupakan negative entrenchment effect. Dengan lebih tingginya hak kendali dibandingkan dengan hak arus kasnya, pemegang saham pengendali dapat dengan leluasa mengekspropriasi kekayaan perusahaan tanpa harus menanggung biaya yang tinggi bila terjadi kerugian ataupun penurunan nilai perusahaan (Claessens et al. 2000).

Untuk menutupi tindakan ekspropriasinya agar tidak dapat dideteksi oleh pihak eskternal dengan cara menurunkan kualitas pengungkapan (disclosure) pada laporan keuangan perusahaannya (Fan dan Wong, 2005). Dengan adanya penurunan kualitas pengungkapan akan membuat tingkat ketidaksimetrisan informasi antara pemegang saham pengendali dan non pengendali meningkat (Choi et al.2007).

Untuk menjaga tingkat ketidaksimetrisan informasi, pemegang saham pengendali mungkin termotivasi untuk menunjuk kantor akuntan publik (KAP) dengan kualitas audit yang lebih rendah dalam rangka menutupi kon- 
disi finansial perusahaan yang sebenarnya (Choi et al. 2007). Argumen tersebut dibuktikan oleh Choi et al. (2007) dalam penelitian yang dilakukannya terhadap perusahaan-perusahaan publik di Korea yang menemukan adanya hubungan negatif antara selisih hak kendali dan hak arus kas terhadap pemilihan kualitas audit dari akuntan publik.

Namun terjadi suatu kesimpulan yang berlawanan berdasarkan hasil penelitian Fan dan Wong (2005) serta El Ghoul (2007) bahwa adanya potensi konflik keagenan akibat negative entrenchment effect tidak selalu berasosiasi negatif dengan pemilihan kualitas audit dari kantor akuntan publik. Fan dan Wong (2005) dalam penelitiannya menyatakan bahwa pada kondisi pasar yang sedang bertumbuh, adanya konflik keagenan yang mengakibatkan turunnya nilai perusahaan serta naiknya cost of capital dipandang dapat merugikan pemegang saham pengendali, karena membuat pemegang saham pengendali kesulitan untuk mengakses pendanaan eksternal (El Ghoul 2007). Padahal, adanya pendanaan eksternal akan sangat berguna untuk menunjang pertumbuhan perusahaan, mengingat besarnya peluang bisnis yang ditawarkan oleh perekonomian pada negara-negara berkembang (Fan dan Wong 2005).

Dihadapkan pada risiko tersebut, pemegang saham pengendali mungkin termotivasi untuk mengarahkan manajemen untuk menunjuk kantor akuntan publik dengan kualitas audit tinggi dalam rangka memitigasi timbulnya kekhawatiran pemegang saham non-pengendali akan adanya potensi konflik keagenan akibat negative entrenchment effect. Pendapat tersebut dibuktikan oleh Fan dan Wong (2005) dalam penelitian yang dilakukannya di Asia Timur, termasuk Indonesia yang hasilnya pada negara berkembang, kantor akuntan publik dengan kualitas audit tinggi terbukti menjadi salah satu mekanisme tata kelola yang dipilih oleh perusahaan untuk memitigasi terjadinya konflik keagenan antara pemegang saham pengendali dan non-pengendali serta untuk meningkatkan kepercayaan investor pada perusahaan.
Berdasarkan argumen tersebut maka hipotesis yang diajukan adalah:

H1: negative entrenchment effect akan berpengaruh terhadap probabilita pemilihan kantor akuntan publik berdasarkan kualitas auditnya

\section{Pengaruh Keefektifan Komite Audit Terhadap Dampak Negative Entrenchment Effect Pada Probabilitas Pemilhan Kantor Akuntan Publik}

Komite audit yang efektif mampu menghasilkan ruang lingkup audit yang lebih luas. Seperti Simunic dan Stein (1996) yang menemukan bahwa komite audit memiliki kemampuan untuk secara langsung mendorong akuntan publik yang telah dikontrak oleh perusahaan untuk meningkatkan ruang lingkup audit sesuai hasil analisa komite audit. Lalu Knapp (1991) yang menemukan bahwa komite audit memiliki kemampuan untuk memitigasi adanya ancaman pemutusan kontrak akuntan publik serta pembatasan ruang lingkup audit oleh manajemen.

Berbagai temuan di atas mengindikasikan bahwa tingkat keefektifan komite audit mampu mempengaruhi keleluasaan pemegang saham pengendali dalam memanipulasi laporan keuangan dan secara tidak langsung insentif atas negative entrenchment effect. Argumen ini dibuktikan oleh Sharma et al. (2011) yang menemukan adanya hubungan positif antara audit client importance dengan earning management semakin diperlemah ketika komite audit perusahaan efektif. Mengacu pada penjelasan tersebut dihipotesiskan sebagai berikut:

H2: Efektifas komite audit akan mempengaruhi dampak negative entrenchment effect terhadap probabilita pemilihan KAP berdasarkan kualitas auditnya.

\section{METODA PENELITIAN}

\section{Jenis dan Sumber Data}

Penelitin ini menggunakan jenis data sekunder perusahaan manufaktur yang terdaftar di Bursa Efek Indonesia (BEI) dari tahun 2010 sampai dengan 2013. Data diperoleh dari 
Laporan Tahunan perusahaan yang diperoleh dari situs Bursa Efek Indonesia (www.idx.co.id), Datastream Thomson Reuters di Pusat Data Ekonomi dan Bisnis Fakultas Ekonomi Universitas Indonesia (PDEBFEUI) serta Indonesia Capital MarketDirectory (ICMD). Untuk penelusuran struktur kepemilikan dilakukan dengan menggunakan data akte pendirian persero yang didapatkan dari Departemen Hukum dan Hak Kemanusiaan Republik Indonesia.

\section{Populasi dan sampel}

Populasi pada penelitian ini adalah seluruh perusahaan yang terdaftar pada Bursa Efek Indonesia dari tahun 2010-2013. Pemilihan sampel dilakukan dengan metode purposive sampling, yaitu metode pemilihan sampel berdasarkan kriteria-kriteria tertentu dengan tujuan agar sampel yang didapatkan dapat merepresentasikan penelitian yang dilakukan. Kriteria yang ditetapkan oleh peneliti adalah: 1) Perusahaan manufaktur yang terdaftar pada Bursa Efek Indonesia dari tanggal 31 Desember 2010 hingga 31 Desember 2012 (tidak pernah delisting, suspensi saham ataupun go private). 2) Perusahaan yang data kepemilikan sahamnya dapat dilakukan penelusuran hingga ke pemegang saham pengendali akhir dan dapat diukur besaran entrenchment effectnya. 3) Perusahaan yang nilai ekuitasnya tidak negatif. 4) Perusahaan yang memiliki seluruh komponen yang diperlukan untuk pengukuran variabel-variabel di dalam model penelitian ini. 5) Perusahaan tidak terkatagori Asing Tapi Indonesia (ASTINDO) yaitu perusahaan yang pada awal pendiriannya dimiliki oleh keluarga tetapi kemudian mengalami perubahan kepemilikan menjadi kepemilikan asing di tahun-tahun berikutnya dengan kendali masih di keluarga yang sama. 6) Perusahaan yang memiliki seluruh komponen yang diperlukan untuk pengukuran variabel-variabel di dalam model penelitian ini.

Berdasarkan kriteria pemilihan sampel tersebut diperoleh total sampel dalam penelitian ini setiap tahunnya masing-masing sebanyak 77 perusahaan selama 4 tahun (2010-
2013). Tabel 1 berikut menyajikan jumlah sampel berdasarkan jenis kepemilikan saham.

Tabel 1: Sampel Penelitian

Operasionalisasi Variabel

\begin{tabular}{ccc}
\hline $\begin{array}{c}\text { Kepemilikan } \\
\text { Perusahaan }\end{array}$ & $\begin{array}{c}\text { Jumlah } \\
\text { Perusahaan }\end{array}$ & Prosentase \\
\hline Asing & 38 & $49 \%$ \\
Keluarga & 37 & $48 \%$ \\
Pemerintah & 2 & $3 \%$ \\
\hline
\end{tabular}

\section{Variabel Terikat}

Variable terikat dalam penelitian ini adalah kualitas audit. Kualita audit diproksikan menggunakan ukuran kantor akuntan publik. Proksi ini sesuai dengan penelitian DeAngelo (1981) yang menemukan adanya pengaruh positif antara ukuran dengan kualitas audit dari sebuah kantor akuntan publik, yang artinya semakin besar ukuran kantor akuntan publik semakin tinggi pula kualitas audit dari kantor akuntan publik tersebut dan sebaliknya semakin kecil ukuran kantor akuntan publik semakin rendah pula kualitas audit dari kantor akuntan publik tersebut.

Mengacu pada penelitian Soedibyo (2010), pada penelitian ini ukuran dari kantor akuntan publik akan dibagi menjadi 3 golongan dengan detail sebagai berikut: a) Golongan satu, yaitu KAP third tier dengan jumlah staff profesional $<100$ orang. b) Golongan dua, yaitu untuk KAP second tier dengan jumlah staff profesional antara 100 400 orang. c) Golongan tiga, yaitu untuk KAP besar (Big four) dengan jumlah staff profesional $>400$.

\section{Variabel Bebas}

Variabel bebas dalam penelitian ini adalah cash flow leverage. Variabel cash flow leverage merupakan rasio hak kendali dibandingkan dengan hak arus kas. Mengacu pada penelitian Diyanty (2012), cash flow leverage digunakan sebagai proksi negative entrenchment effect pemegang saham pengendali akhir berupa insentif ekspropriasi yang dilakukan pemegang saham pengendali terhadap pemegang saham non-pengendali. 


\section{Cash Flow Leverage $=\frac{\text { Hak Kendali }}{\text { Hak Arus Kas }}$}

Menurut Claessens et al. (2000), definisi pengendali akhir adalah pemegang saham dengan hak kendali yang sangat besar sehingga dapat mempengaruhi arah kebijakan perusahaan dan tidak dikontrol oleh pihak luar. Dalam menghitung cash flow leverage perlu dihitung terlebih dahulu hak kendali dan hak arus kasnya.

Menurut La Porta et al. (1999) hak arus kas terdiri dari hak arus kas langsung dan hak arus kas tidak langsung. Hak arus kas langsung adalah persentase saham yang dimiliki oleh pemegang saham pengendali pada perusahaan publik atas nama dirinya sendiri. Hak arus kas tidak langsung adalah penjumlahan atas hasil perkalian persentase kepemilikan pemegang saham pengendali akhir dalam setiap rantai kepemilikan (LaPorta et al. 1999).

Hak arus kas $=$ Hak arus kas langsung + Hak arus kas tidak langsung

Menurut La Porta et al. (1999) hak kendali terdiri atas hak kendali langsung dan hak kendali tidak langsung. Hak kendali langsung adalah persentase saham yang dimiliki oleh pemegang saham pengendali atas nama dirinya sendiri pada perusahaan-perusahaan. Hak kendali tidak langsung adalah penjumlahan hak kendali minimum (the weakest link) pada setiap rangkai kepemilikan.

Hak kendali $=$ Hak kendali langsung + Hak kendali tidak langsung

\section{Variabel Moderasi}

Variabel moderasi dalam penelitian ini adalah efektivitas komite audit. Pengukuran efektivitas komite audit menggunakan metode scoring Hermawan (2009) yang mencakup pengukuran independensi, aktivitas, serta kompetensi. Perhitungan skor berdasarkan informasi yang tertera dalam laporan keuangan perusahaan. Penilaian akan dilakukan berdasarkan daftar pertanyaan yang disusun mengacu pada pertanyaan yang dibuat oleh Indonesian Institute for Corporate Directorship (IICD) serta modifikasi yang pernah dilakukan oleh Hermawan (2009) mengacu pada literatur yang mendukung penelitian ini. Untk setiap pertanyaan, penilaian akan terdiri atas 2 kemungkinan jawaban, yaitu Good dan Poor, dan 3 kemungkinan jawaban, yaitu Good, Fair, dan Poor. Jawaban Good diberi nilai 3, Fair diberi nilai 2, dan Poor diberi nilai 1 . Untuk pertanyaan yang tidak dapat diperoleh informasinya dari laporan tahunan perusahaan, maka akan diberi jawaban Poor (nilai 1). Maksimum skor yang bisa didapatkan oleh sebuah perusahaan adalah 33 .

\section{Variabel Kontrol}

Variabel kontrol dalam penelitian ini terdiri dari financial leverage, ukuran perusahaan, profitabilitas, likuiditas, potensi pertumbuhan dan jumlah komisaris independen.

\section{Financial leverage}

Financial leverage dihitung dari total utang dibagi dengan total aset. Rasio ini mengukur seberapa besar aset yang dimiliki perusahaan dilihat dari sisi hutang/pinjaman. Semakin besar rasio financial leverage maka semakin besar pula ketergantungan perusahaan terhadap kreditur dan semakin besar pula biaya bunga yang harus dibayar oleh perusahaan. Berbagai penelitian terdahulu menemukan hasil yang cukup beragam berkenaan dengan pengaruh leverage terhadap pemilihan kantor akuntan publik (Grossman dan Hart 1982).

\section{Ukuran perusahaan (SIZE)}

Ukuran perusahaan (size) dihitung berdasarkan logaritma natural dari total aset perusahaan (Faccio et al. 2001). Beberapa penelitian sebelumnya menemukan bahwa ukuran perusahaan memiliki hubungan positif dengan pemilihan kantor akuntan publik, seperti Willenborg (1999) yang menyatakan bahwa perusahaan dengan ukuran yang besar umumnya lebih kompleks sehingga membutuhkan proses audit yang lebih kompleks dengan dukungan sumber daya manusia dan sumber daya teknologi yang lebih tinggi. 
Kedua sumber daya tersebut dapat ditemukan pada kantor akuntan publik dengan ukuran yang lebih besar.

\section{Profitabilitas (ROA)}

Profitabilitas diukur dengan Return on Assets (ROA). Profitabilitas perusahaan diperkirakan akan berpengaruh positif terhadap kemungkinan dipilihnya kantor akuntan publik dengan kualitas audit lebih tinggi. Berikut adalah formula yang digunakan untuk menghitung ROA perusahaan setiap tahunnya.

ROA $_{i t} \frac{{\text { Net } \text { Income }_{i t}}_{\text {Total Asset }}}{\text { it }}$

\section{Likuiditas (CURR)}

CURR merupakan proksi yang menggambarkan tingkat likuiditas perusahaan. CURR dihitung dari total current asset dibagi dengan total ssset perusahaan. Mengacu pada hasil penelitian Copley dan Douhett (2002), peneliti akhirnya memperkirakan bahwa peningkatan likuiditas akan menyebabkan dipilihnya kantor akuntan publik dengan kualitas audit lebih rendah.
CURR $_{i t} \frac{\text { Current Asset }_{\text {it }}}{\text { Total Asset }_{i t}}$

\section{Potensi Pertumbuhan (ATURN)}

ATURN merupakan proksi yang menggambarkan potensi pertumbuhan perusahaan. ATURN dihitung dari total sales dibagi dengan total asset perusahaan. Lin dan Liu 2009; dan Anderson et al. 2004 membuktikan adanya bahwa seiring dengan meningkatnya potensi growth perusahaan perusahaan cenderung menunjuk kantor akuntan publik dengan kualitas audit lebih tinggi.

\section{Jumlah Komisaris Independen}

O'Sulliva (2000) mengemukakan bahwa terdapat hubungan positif antara proporsi komisaris independen terhadap kualitas audit. Selain itu Beasley dan Petroni (2001) juga mengemukakan bahwa semakin tinggi proporsi komisaris independen semakin tinggi kemungkinan dipilihnya akuntan publik yang memiliki reputasi tinggi. Tabel 2 berikut menyajikan operasionalisasi variable penelitian.

Tabel 2: Operasionalisasi Variabel

\begin{tabular}{|c|c|}
\hline \multicolumn{2}{|r|}{ Variabel Dependen } \\
\hline $\operatorname{Ln} \frac{\mathbf{P}\left(\mathrm{KAP}_{\mathbf{i}} \leq \boldsymbol{m}\right)}{\mathbf{P}\left(\mathrm{KAP}_{\mathbf{i}}>m\right)}$ & $\begin{array}{l}\text { Probabilita }(\mathrm{P}) \text { dipilihnya KAP dengan ukuran lebih rendah } \\
\text { dibandingkan dengan KAP dengan ukuran lebih tinggi }\end{array}$ \\
\hline \multicolumn{2}{|r|}{ Variabel Independen } \\
\hline $\mathrm{CFL}_{\text {it }}$ & $\begin{array}{l}\text { Cash Flow Leverage }=\text { hak kendali dibagi dengan hak arus kas } \\
\text { pemegang saham pengendali akhir }\end{array}$ \\
\hline \multicolumn{2}{|r|}{ Variabel Moderasi } \\
\hline EFKOMAUD $_{\text {it }}$ & $\begin{array}{l}\text { Prosentase score efektivitas komite audit tahun berjalan } \\
\left(\text { Score }_{i /} / \text { Max Score) }\right.\end{array}$ \\
\hline \multicolumn{2}{|r|}{$\begin{array}{l}\text { Variabel Kontrol } \\
\end{array}$} \\
\hline $\mathbf{L E V}_{\text {it }}$ & Leverage Perusahaan (Total Debt ${ }_{i} /$ Total Asset $_{i t}$ ) \\
\hline $\mathbf{S I Z E}_{\text {it }}$ & Ukuran Perusahaan (Ln Total Asset $\left.{ }_{i t}\right)$ \\
\hline $\mathbf{R O A}_{i t}$ & Return on assets perusahaan (Net Income $i /$ Total Asset $\left.{ }_{i t}\right)$ \\
\hline $\mathbf{C U R R}_{\text {it }}$ & Likuiditas $_{\mathrm{it}}($ Current Asset/Total Asset) \\
\hline $\mathbf{A T U R N}_{\mathrm{it}}$ & Potensi Pertumbuhan (Total Sales ${ }_{i t}$ Total Asset $_{i t}$ ) \\
\hline KOMINDEP $_{\text {it }}$ & Jumlah komisaris independen $_{\text {it }}$ \\
\hline
\end{tabular}




\section{Metode Analisis Data}

Metode analisis data yang akan digunakan pada penelitian ini atalah metode analisa data kuantitatif menggunakan metode ordered logistic regression dengan pendekatan maximum likelihood estimation (MLE). Data penelitian ini akan berbentuk data panel karena berupa gabungan antara data cross section (perusahaan) dan time series (tahun). Adapun model penelitian yang akan digunakan adalah:

$$
\boldsymbol{L n} \frac{\mathbf{P}\left(\mathbf{K A P}_{\mathbf{i}} \leq \boldsymbol{m}\right)}{\mathbf{P}\left(\mathbf{K A P}_{\mathbf{i}}>m\right)}=\alpha_{m}-\boldsymbol{\beta}^{\prime} \boldsymbol{x}
$$

Di mana:

$$
\begin{aligned}
& \beta^{\prime} x=\beta_{0}+\beta_{1} C F L_{i t}+\beta_{2} E F E K O M A U D_{i t} \\
& +\beta_{3} \text { EFEKOMAUD } \\
& \text { *WEDGE } \boldsymbol{W}_{i t}+\beta_{4} L E V_{i t} \\
& +\beta_{5} S I Z E_{i t}+\beta_{6} R O A_{i t} \\
& +\beta_{7} C U R R_{i t} \\
& +\beta_{8} A_{T U R N} \\
& +\beta_{9} K O M I N D E P_{i t}+\varepsilon_{i t}
\end{aligned}
$$

\section{HASIL DAN PEMBAHASAN}

\section{Statistik Deskriptif}

Berdasarkan data yang diperoleh rata-rata sekitar $49 \%$ perusahaan terbukti dikendalikan oleh keluarga. Cukup tingginya prosentase keluarga sebagai pemegang saham pengendali akhir menunjukkan bahwa kepemilikan keluarga cukup dominan di Indonesia.

Berdasarkan data pada tabel 3 terlihat bahwa rata-rata perusahaan sampel memiliki hak kendali yang melebihi hak arus kas. Hal ini mencerminkan adanya potensi negative entrenchment effect yang cukup besar dari pemegang saham pengendali.

Berkenaan dengan penunjukkan kantor akuntan publik, pada tabel 4 dapat dilihat bahwa sepanjang tahun 2010 sampai pada tahun 2013, dari total 308 sampel perusahaan, 131 diantaranya memilih untuk menunjuk kantor akuntan publik second tier, 122 diantaranya memilih untuk menunjuk kantor akuntan publik Big four, dan sisanya memilih untuk menunjuk kantor akuntan publik third tier. Dari data tersebut dapat diketahui bahwa kantor akuntan publik second tier merupakan kantor akuntan publik yang mayoritas ditunjuk oleh perusahaan sampel, kemudian diikuti oleh kator akuntan publik big four dan terakhir kantor akuntan publik third tier.

Apabila dilihat dari trendnya dapat diketahui bahwa jumlah perusahaan yang menggunakan jasa kantor akuntan publik big four dan second tier terbukti mengalami kenaikan setiap tahunnya. Namun, jumlah perusahaan yang menggunakan jasa kantor akuntan publik third tier terbukti mengalami penurunan setiap tahunnya. Terjadinya fenomena tersebut mengindikasikan bahwa dari tahun ke tahun perusahaan cenderung termotivasi untuk menunjuk kantor akuntan publik dengan ukuran yang lebih besar.

Tabel 3: Statistik Deskriptif Variabel Cash Flow Leverage

\begin{tabular}{lcc}
\hline \multicolumn{1}{c}{ Kepemilikan Perusahaan } & Jumlah Perusahaan & Prosentase \\
\hline Asing & 38 & $49 \%$ \\
Keluarga & 37 & $48 \%$ \\
Pemerintah & 2 & $3 \%$ \\
Jumlah & $\mathbf{7 7}$ & $\mathbf{1 0 0 \%}$ \\
\hline
\end{tabular}

Tabel 4: Jumlah Kantor Akuntan Publik yang Ditunjuk Perusahaan Sampel Tahun $2010-2013$

\begin{tabular}{lcccccc}
\hline \multicolumn{1}{c}{ Size KAP } & $\mathbf{2 0 1 0}$ & $\mathbf{2 0 1 1}$ & $\mathbf{2 0 1 2}$ & $\mathbf{2 0 1 3}$ & Total & Rata-Rata \\
\hline Third Tier & 17 & 14 & 13 & 11 & 55 & 13.75 \\
Second Tier & 32 & 33 & 32 & 34 & 131 & 32.75 \\
BIG 4 & 28 & 30 & 32 & 32 & 122 & 30.50 \\
\hline
\end{tabular}


Tabel 5: Efektivitas Komite Audit

\begin{tabular}{ccccc}
\hline EFEKOMAUD & $\mathbf{2 0 1 0}$ & $\mathbf{2 0 1 1}$ & $\mathbf{2 0 1 2}$ & $\mathbf{2 0 1 3}$ \\
\hline Mean & $69.22 \%$ & $69.58 \%$ & $70.05 \%$ & $72.22 \%$ \\
Min & $36.36 \%$ & $36.36 \%$ & $36.36 \%$ & $39.39 \%$ \\
Max & $93.94 \%$ & $87.88 \%$ & $84.85 \%$ & $90.91 \%$ \\
Median & $69.70 \%$ & $69.70 \%$ & $72.73 \%$ & $72.73 \%$ \\
Standart Deviasi & $12.72 \%$ & $12.27 \%$ & $11.53 \%$ & $11.48 \%$ \\
\hline
\end{tabular}

Data terkait efektivitas komite audit disajikan pada table 5. Efektivitas komite audit ditentukan berdasarkan rasio antara nilai yang didapatkan dari proses scoring dibandingkan dengan total maksimum nilai yang bisa didapatkan dari proses scoring. Semakin tinggi rasio efektivitas komite audit semakin efektif pula komite audit tersebut. Hasil statistik deskriptif menunjukkan bahwa selama tahun 2010 hingga tahun 2013 rasio efektivitas komite audit secara konstan mengalami peningkatan. Dari yang awalnya $69,22 \%$ meningkat menjadi $69,58 \%$ pada tahun 2011 , kemudian menjadi $70,05 \%$ pada tahun 2012 , lalu menjadi $72,22 \%$ pada tahun 2013. Adanya peningkatan dari rasio efektivitas komite audit menjadi sebuah indikasi bahwa rata-rata perusahaan memiliki komite audit yang semakin efektif setiap tahunnya.

\section{Hasil Uji Hipotesis}

\section{Pengaruh Negative Entrenchment Effect Pemegang Saham Pengendali Akhir Terhadap Probabilitas Pemilihan KAP Berdasarkan Kualitas Auditnya}

Pengujian model penelitian ini telah melewati uji multikolinieritas, uji proportional odss assumption serta uji kelayakan keseluruhan model. Hasil pengujian dapat dilihat pada tabel 6. Pada tabel ini dapat dilihat bahwa pengujian generalized ordinal logit membagi variabel dependen menjadi dua katagori. Katagori pertama merupakan perbandingan antara probabilita dipilihnya kombinasi KAP big four dan second tier dengan probabilita dipilihnya KAP third tier, sementara katagori kedua merupakan perbandingan antara probabilita dipilihnya KAP big four dibandingkan dengan probabilitas dipilihnya KAP non-big four. Melalui hasil regresi antar katagori, dapat diketahui bahwa baik pada katagori pertama maupun katagori kedua, variabel cash flow leverage secara konsisten memiliki koefisien positif dengan tingkat signifikansi dibawah alpha $10 \%$. Hal ini memiliki arti bahwa ketika perusahaan dihadapkan pada pilihan antara KAP big four, second tier dan third tier, peningkatan prosentase hak kendali atas hak arus kas akan secara konsisten berpengaruh terhadap dipilihnya kantor akuntan publik dengan ukuran yang lebih besar.

Hasil penelitian ini menunjukkan bahwa seiring dengan meningkatnya potensi konflik keagenan akibat negative entrenchment effect, perusahaan cenderung menunjuk kantor akuntan publik dengan kualitas audit lebih tinggi dalam rangka meningkatkan kepercayaan pemegang saham non-pengendali terhadap kualitas dan keandalan laporan keuangan perusahaan. Hasil penelitian ini sejalan dengan hasil penelitian Fan \& Wong (2005) serta El-Ghoulet al.(2007).

Sesuai penelitian Claessens et al. (2002) yang menemukan adanya negative entrenchment effect umumnya dikompensasi pemegag saham non -pengendali baik dengan menurunkan nilai perusahaan ataupun dengan meningkatkan cost of capital perusahaan. Fan dan Wong (2005) dalam penelitiannya menyatakan bahwa pada kondisi pasar yang sedang bertumbuh, adanya penurunan nilai perusahaan serta peningkatan cost of capital dipandang dapat merugikan pemegang saham pengendali karena membuat pemegang saham pengendali kesulitan untuk mengakses pendanaan eksternal. Dihadapkan pada risiko tersebut, pemegang saham pengendali menjadi termotivasi untuk mengarahkan manajemen untuk menunjuk kantor akuntan publik dengan kualitas audit lebih tinggi dalam rangka meningkatkan kepercayaan investor atas kre- 
dibilitas dan keandalan laporan keuangan perusahaan.

Argumen tersebut dibuktikan oleh Fan dan Wong (2005) dalam penelitian yang dilakukannya di Asia Timur, termasuk Indonesia yang hasilnya menemukan bahwa perusahaanperusahaan dengan potensi konflik keagenan akibat negative entrenchment effect terbukti cenderung memilih kantor akuntan publik big 5 dibandingkan dengan kantor akuntan publik non-big 5. Hasil penelitian Fan dan Wong
(2005) tersebut juga dikonfirmasi oleh ElGhoul et al. (2007) yang dalam penelitiannya menemukan bahwa di sebagian besar negara Eropa, khususnya negara-negara selain United Kingdom, terjadinya peningkatan potensi konflik keagenan akibat negative entrenchment effect terbukti mempengaruhi kecenderungan perusahaan untuk memilih kantor akuntan publik big four dibandingkan dengan kantor akuntan publik non-big four.

Tabel 6: Hasil Regresi Antar Kategori

\begin{tabular}{|c|c|c|c|c|c|c|c|}
\hline & \multirow{2}{*}{ Variabel } & \multicolumn{6}{|c|}{ Partial Proportional Odds Model } \\
\hline & & Prediksi & Koefisien & Stand.Err & $\mathbf{Z}$ & $\mathbf{P}>|\mathbf{z}|$ & \\
\hline & \multicolumn{7}{|c|}{ Uji Kelayakan Model } \\
\hline \multicolumn{8}{|c|}{ LR chi2(9) } \\
\hline \multicolumn{8}{|c|}{0.0000} \\
\hline \multicolumn{8}{|c|}{0.2675} \\
\hline \multicolumn{8}{|c|}{ Uji Hipotesa (Per Komparasi Katagori KAP) } \\
\hline \multirow{9}{*}{1} & CFL & & 0.9920 & 0.3901 & 2.54 & 0.0110 & $* *$ \\
\hline & Efekomaud & & 2.4182 & 1.0013 & 2.41 & 0.0160 & $* *$ \\
\hline & Efekomaud*CFL & & 7.9245 & 2.9071 & 2.73 & 0.0060 & $* * *$ \\
\hline & Lev & + & 0.5685 & 1.0051 & 0.57 & 0.2860 & \\
\hline & Size & + & -0.1225 & 0.1692 & -0.72 & 0.2345 & \\
\hline & Roa & + & 3.9075 & 1.8534 & 2.11 & 0.0175 & $* *$ \\
\hline & Curr & - & 1.3016 & 0.8862 & 1.47 & 0.0710 & $*$ \\
\hline & Komindep & + & 1.3642 & 0.3233 & 4.22 & 0.0000 & $* * *$ \\
\hline & Constanta/1 & & 2.0158 & 4.5412 & 0.44 & 0.6570 & \\
\hline \multirow{9}{*}{2} & CFL & & 0.9920 & 0.3901 & 2.54 & 0.0110 & $* *$ \\
\hline & Efekomaud & & 2.4182 & 1.0013 & 2.41 & 0.0160 & $* *$ \\
\hline & Efekomaud*CFL & & 7.9245 & 2.9071 & 2.73 & 0.0060 & $* * *$ \\
\hline & Lev & + & -3.5515 & 1.0046 & -3.54 & 0.0000 & $* * *$ \\
\hline & Size & + & 0.9567 & 0.1473 & 6.49 & 0.0000 & $* * *$ \\
\hline & Roa & + & 3.9075 & 1.8534 & 2.11 & 0.0175 & $* *$ \\
\hline & Curr & - & -2.5920 & 0.9557 & -2.71 & 0.0035 & $* * *$ \\
\hline & Komindep & + & 0.5026 & 0.2274 & 2.21 & 0.0135 & $* *$ \\
\hline & Constanta/2 & & -26.2549 & 4.0937 & -6.41 & 0.0000 & $* * *$ \\
\hline \multicolumn{8}{|c|}{ ****signifikan pada level 1\%, **signifikan pada level 5\%, *signifikan pada level $10 \%$} \\
\hline & $=$ Probabilita KAP & Third & Tier versus & KAP $S e c$ & nd Tic & $+\mathrm{KAP}$ & Big 4 \\
\hline \multicolumn{8}{|c|}{$\begin{array}{l}\text { KAP: } 1 \text { jika perusahaan menggunakan kantor akuntan publik third tier, } 2 \text { jika perusahaan } \\
\text { menggunakan kantor akuntan publik second tier, dan } 3 \text { jika perusahaan menggunakan kantor } \\
\text { akuntan publik Big 4; WEDGE: hak kendali - hak arus kas; EFEKOMAUD: prosentase } \\
\text { dari score efektivitas komite audit; LEV: rasio leverage perusahaan; SIZE: Logaritma } \\
\text { natural dari total aset perusahaan; ROA: return on asset; CURR: current asset/total Asset; } \\
\text { KOMINDEP : jumlah komisaris independen. }\end{array}$} \\
\hline
\end{tabular}


Secara garis besar hasil penelitian ini menunjukkan bahwa kantor akuntan publik dengan kualitas audit lebih tinggi terbukti menjadi salah satu mekanisme tata kelola yang dipilih oleh perusahaan untuk memitigasi konflik keagenan antara pemegang saham pengendali dan non-pengendali. Hal itu dibuktikan dari meningkatnya probabilitas dipilihnya kantor akuntan publik dengan ukuran kualitas audit yang lebih tinggi ketika cash flow leverage pemegang saham pengendali akhir meningkat.

\section{Pengaruh Moderasi Keefektifan Komite Audit Terhadap Pengaruh Negative Entren- chment Effect pada Probabilita Pemilihan Kantor Akuntan Publik Berdasarkan Kualitas Auditnya}

Hasil penelitian menunjukkan bahwa tingkat keefektifan komite audit secara signifikan mempengaruhi dampak negative entrenchment effect pada pemilihan kantor akuntan publik berdasarkan kualitas auditnya. Hasil penelitian ini mendukung hasil penelitian Dhaliwal, Naiker dan Navassi (2006). Dalam hal ini adanya komite audit yang efektif mampu memperkuat motivasi pemegang saham pengendali akhir untuk menunjuk kantor akuntan publik dengan kualitas audit lebih tinggi. Oleh karena itu berdasarkan hasil regresi hipotesis kedua dapat didukung.

Hasil pengujian juga menunjukkan bahwa ketika perusahaan dihadapkan pada pilihan antara kantor akuntan publik big four, second tier dan third tier, dengan adanya komite audit yang efektif terbukti memperkuat probabilita dipilihnya kombinasi kantor akuntan publik big four dan second tier. Sementara ketika perusahaan dihadapkan pada pilihan antara kantor akuntan publik Big four dan non-Big four, dengan adanya komite audit yang efektif terbukti memperkuat probabilita dipilihnya kantor akuntan publik Big four dibandingkan dengan probabilita dipilihnya kantor akuntan publik non-Big four.

Carcello dan Neal (2003) dalam penelitiannya menyimpulkan bahwa ketika sebuah perusahaan mengalami kesulitan finansial, adanya komite audit yang efektif cenderung mempengaruhi munculnya opini audit going concern dari akuntan publik yang ditugaskan untuk mengaudit laporan keuangan perusahaan tersebut. Simunic dan Stein (1996) dalam penelitiannya juga menyimpulkan komite audit memiliki kemampuan untuk secara langsung mendorong akuntan publik yang telah dikontrak oleh perusahaan untuk meningkatkan ruang lingkup audit sesuai hasil analisa komite audit. Abbott dan Parker (2000) menyatakan bahwa perusahaan yang komite auditnya berisikan anggota independen dengan frekuensi rapat dua kali dalam satu tahun cenderung untuk memilih akuntan publik yang berasal dari kantor akuntan publik Big 6. Serta, Dhaliwal, Naiker dan Navassi (2006) berhasil membuktikan bahwa adanya komite audit yang efektif mampu mempengaruhi kecenderungan atas dipilihnya kantor akuntan publik dengan kualitas audit yang tinggi. Dengan demikian penelitian ini mendukung penelitian sebelumnya karena memberi kesimpulan yang sama yaitu bahwa semakin efektif komite audit, maka semakin mendorong perusahaan untuk memilih KAP yang memiliki kualitas audit yang tinggi. Dengan kualitas audit yang tinggi diharapkan dapat memberikan hasil audit yang berkualitas sehingga mampu melindungi pemegang saham non-pengendali dari potensi konflik keagenan dengan cara mempengaruhi pemegang saham pengendali untuk menunjuk kantor akuntan publik dengan kualitas audit yang lebih tinggi.

\section{Analisis Variabel Kontrol}

Variabel leverage tidak memiliki pengaruh yang signifikan terhadap probabilita pemilihan kantor akuntan publik berdasarkan kualitas auditnya, tetapi pada katagori kedua adanya peningkatan variabel leverage terbukti mempengaruhi dipilihnya kantor akuntan publik dengan kualitas audit lebih rendah. Hasil regresi tersebut memiliki arti bahwa ketika perusahaan dihadapkan pada pilihan antara kombinasi kantor akuntan publik big four dan second tier dengan kantor akuntan publik third tier, peningkatan leverage cenderung tidak mempengaruhi keputusan pemilihan kantor akuntan publik pada sebuah perusahaan. Namun, ketika perusahaan dihadapkan pada 
pilihan antara kantor akuntan publik big four dan non-big four, peningkatan leverage akan menyebabkan probabilita dipilihnya kantor akuntan publik big four lebih rendah dibandingkan dengan kantor akuntan publik non-big four. Hasil penelitian ini mendukung penelitian Titman dan Trueman (1986).

Ukuran perusahaan (size) ternyata berpengaruh signifikan terhadap probabilita pemilihan kantor akuntan publik ketika perusahaan dihadapkan pada pilihan antara kantor akuntan publik big four dan non-big four. Hasil regresi tersebut sesuai dengan penelitian Willenborg (1999).

Untuk variabel profitabilitas (ROA) dapat dibuktikan bahwa seiring dengan terjadinya peningkatan ROA maka probabilita dipilihnya kantor akuntan publik dengan kualitas audit lebih tinggi juga meningkat. Ketika perusahaan dihadapkan pada pilihan antara kantor akuntan publik big four, second tier dan third tier, adanya peningkatan ROA akan menyebabkan probabilita dipilihnya kombinasi kantor akuntan publik big four dan second tier lebih tinggi dibandingkan dengan probabilita kantor akuntan publik third tier. Lebih lanjut ketika perusahaan dihadapkan pada pilihan antara kantor akuntan publik big four dan non-big four, adanya peningkatan ROA akan menyebabkan probabilita dipilihan kantor akuntan publik big four lebih tinggi dibandingkan dengan kantor akuntan publik non-big four. Hasil regresi ini sesuai dengan penelitian Lin dan Liu (2009).

Dari analisis regresi tersebut terbukti bahwa jumlah komisaris independen dalam sebuah perusahaan memiliki pengaruh positif signifikan terhadap probabilita pemilihan kantor akuntan public. Hasil regresi tersebut sesuai dengan penelitian Beasley dan Petroni (2001).

\section{Analisis Efek Marginal}

Hasil dari pengujian efek marginal menujukkan bahwa adanya peningkatan CFL akan menyebabkan probabilita dipilihnya kantor akuntan publik third tier dan second tier menurun tetapi. Sementara untuk kantor akuntan publik big four, adanya peningkatan
CFL terbukti meningkatkan probabilita dipilihnya kantor akuntan publik. Hal ini menunjukkan bahwa ketika terjadi peningkatan negative entrenchment effect, perusahaan lebih bertendensi untuk menunjuk kantor akuntan publik dengan kualitas audit lebih tinggi.

Berkenaan dengan variabel interaksi efektivitas komite audit dengan negative entrenchment effect, pengujian efek marginal menunjukkan bahwa peningkatan keefektifan komite audit akan memperkuat probabilita dipilihnya kantor akuntan publik big four. Sementara untuk kantor akuntan publik third tier dan second tier, peningkatan keefektifan komite audit akan memperlemah probabilita dipilihnya kedua kantor akuntan public. Hal ini menunjukkan bahwa peningkatan keefektifan komite audit akan makin mendorong pengaruh negative entrenchment effect terhadap probabilita dipilihnya kantor akuntan publik dengan kualitas audit lebih tinggi.

\section{SIMPULAN}

Hasil penelitian ini berhasil membuktikan adanya pengaruh positif antara negative entrenchment effect dengan pemilihan kantor akuntan publik dengan kualitas audit lebih tinggi. Dengan kata lain seiring dengan terjadinya peningkatan potensi konflik keagenan akibat negative entrenchment effect, probabilita dipilihnya kantor akuntan publik dengan kualitas audit lebih tinggi juga meningkat. Hasil penelitian ini sesuai dengan hasil penelitian Fan dan Wong (2005) serta ElGhoulet al.(2007).

Mengacu pada penelitian Fan dan Wong (2005), ditemukannya pengaruh positif antara negative entrenchment effect terhadap probabilitas pemilihan kantor akuntan publik dengan kualitas audit lebih tinggi dapat dilandasi oleh argumen bahwa, pada kondisi pasar yang sedang bertumbuh, adanya konflik keagenan yang mengakibatkan turunnya nilai perusahaan serta naiknya cost of capital akan merugikan pemegang saham pengendali karena membuat pemegang saham pengendali kesulitan dalam mengakses pendanaan eksternal (El Ghoul et al.2007). Oleh karena itu 
pemegang saham pengendali cenderung termotivasi untuk mengarahkan perusahaan untuk menunjuk kantor akuntan publik dengan kualitas audit lebih tinggi dalam rangka meningkatkan kepercayaan investor dan meningkatkan akses terhadap pendanaan eksternal.

Peningkatan keefektifan komite audit terbukti memperkuat pengaruh negative entrenchment effect terhadap probabilita dipilihnya kantor akuntan publik dengan kualitas audit lebih tinggi. Temuan tersebut memperlihatkan bahwa sebagai salah satu organ pengawasan internal, komite audit yang efektif terbukti mampu untuk melindungi pemegang saham non-pengendali dari potensi tindakan ekspropriasi pemegang saham pengendali.

\section{Keterbatasan dan Saran}

Keterbatasan dalam penelitian ini sebagai berikut: 1). Rentang sampel pada penelitian ini hanya meliputi tahun 2010 hingga 2013 dan terbatas pada industri manufaktur. Penggunaan data sampai dengan tahun 2013 dan hanya industri manufaktur dikhawatirkan tidak cukup mencerminkan kondisi seluruh perusahaan publik yang sebenarnya saat ini. Disarankan untuk penelitian selanjutnya bisa mencakup seluruh industri.2). Penelusuran struktur kepemilikan tidak dilakukan terhadap perusahaan asing, sehingga terdapat risiko bahwa ketika perusahaan asing tersebut ternyata merupakan afiliasi dari pemegang saham pengendali akhir, peneliti tidak memasukan hak kendali dan hak arus kas perusahaan asing tersebut ke dalam proses penghitungan hak kendali dan hak arus kas pemegang saham pengendali akhir. Disarankan untuk penelitian selanjutnya sudah dapat ditemukan sumber data untuk penelusuran kepemilikan asing sehingga dapat diketahui siapa yang mengendalikan perusahaan asing tersebut. 3). Mengacu pada literatur sebelumnya, penelitian ini berfokus pada ukuran kantor akuntan publik (big four, second tier, third tier) sebagai proksi kualitas audit. Namun dalam praktiknya kualitas audit tidak hanya dapat ditentukan berdasarkan besarkecinya kantor akuntan publik. Dapat terjadi fenomena dimana sebuah perusahaan menunjuk kantor akuntan publik dengan ukuran yang lebih kecil tanpa dilandasi oleh motivasi untuk menutupi adanya tindakan ekspropriasi. Diharapkan pada penelitian selanjutnya dapat digunakan proksi kualitas audit yang lebih komprehensif.

\section{Implikasi Penelitian}

Hasil penelitian ini memberikan implikasi bagi regulator maupun investor. Hasil penelitian ini mampu memdorong regulator untuk memperkuat aturan dalam pelaksanaan audit sehingga kualitas audit terjaga dari dampak negative entrenchment effect sehingga kepentingan pemegang saham non pengendali atau minoritas terlindungi. Bagi Investor, hasil penelitian ini dapat memberikan masukan bagi investor untuk lebih concern terhadap auditor dari laporan keuangan investee sehingga bisa memprediksi kualitas audit atas laporan keuangan perusahaan dimana mereka berinvestasi.

\section{DAFTAR REFERENSI}

Abbot, J., dan S. Parker. 2000. Auditor selection and audit committee characteristic. Auditing: A Journal of Practice \& Theory 19 (2): 47-66.

Abbot, J. L., S. Parker, G. Peters, dan K. Raghunandan. 2003. The association between audit committee characteristic and audit fees. Auditing: A Journal of Practice \& Theory 22 (22): 17-32.

Anderson, U., K. Kadous, dan L. Koonce. 2004. The role of incentives tomanage earnings and quantification in auditors' evaluations of management-provided information. Auditing: A Journal of Practice \& Theory 23 (1): 11-27.

Beasley, M., dan K. Petroni. 2001. Board independence and audit firm type. Auditing: A Journal of Practice and Theory 2 (1): 97-114.

Berle, A., dan G. Means. 1932. The Modern Corporation and Private Property. New York: MacMillan. 
Carcello, J., dan T. Neal. 2000. Audit committee composition and auditor reporting. The Accounting Review 75 (4): 453-467.

Carcello, J., dan T. Neal. 2003. Audit committee characteristics and auditor dismissals following "new" going concern reports. The Accounting Review 78 (1): 95-117.

Choi, J., S. Kwak, dan H. Yoo. 2007. The association between audit fees and the ownership structure. Seoul Journal of Bussiness 13 (2): 83-103.

Claessens, S., S. Dảnkov, J. Fan, dan L. Lang. 2000. The separation of ownership and control in East Asian Corporation. Journal of Financial Economics 58 (1-2): 81-112.

Claessens, S., S. Djankov, J. Fan, and L. Lang. 2002. Disentangling the incentive and entrenchment effects of large shareholdings. Journal of Finance 57 (6): 2741-2771.

Claessens, S., J. Fan. 2002. Corporate governance in Asia: A survery. International Review of Finance 3 (2): 71-103.

Copley, P. A., dan E. B. Douthett. 2002. The association between auditor choice, ownership retained, and earnings disclosure by firms making initial public offerings. Contemporary Accounting Research 19 (1): 49-75.

Coffee, C. J. 2010. Dispersed ownership: the theories, the evidence, and the enduring tension between lumpers and splitters. Columbia Law and Economics Working Paper. Number 363.

Dhaliwal, D., V. Naiker, dan F. Navissi. 2006. Audit committee financial expertise, corporate governance and accruals quality: An empirical analysis. Working Paper: University of Arizona (May).
DeAngelo, L. E. 1981. Auditor size and audit quality. Journal of Accounting and Economics 3 (3): 183-199.

Diyanty, V. 2012. Pengaruh kepemilikan pengendali akhir terhadap traksaksi pihak berelasi dan kualitas laba. (Unpublished Dissertation). Program Pascasarjana Akuntansi, Universitas Indonesia, Depok.

El Ghoul, S., O. Guedhami, C. Lennox, dan A. Pittman. 2007. Ownership structure, agency problem, and auditor choice : Evidence form Western European Firms.

http://www.apjfs.org/2007/report/311 guedhami2.pdf (diakses 15 Juni 2015).

Fan, J. P. H., dan T. J. Wong. 2005. Do external auditors perform a corporate governance role in emerging markets? evidence from East Asia. Journal of Accounting Research 43 (1): 35-72.

Hermawan, A. A. 2010. Pengaruh efektifitas fewan komisaris dan komite audit, kepemilikan oleh keluarga dan peran monitoring bank terhadap kandungan informasi laba. Unpublished Dossertation, FE UI Graduate Program in Accouting.

Jensen, M. C., dan W. H. Meckling. 1976. Theory of the firm: managerial behavior, agency costs and ownership structure. Journal of Financial Economics 3 (4): 305-360.

Kim, J. B., C. K. Min, dan C. H. Yi. 2002. Auditor designation, auditor Independence, and Earnings Management: Evidence from Korea. Working Paper, Hong Kong Polytechnic University and Hankuk University of Foreign Studies

Knapp, M. C. 1991. Factors that audit committee members use as surrogates for audit quality. Auditing: A Journal of Practice \& Theory 10 (1) : 35-52.

La Porta, R., F. Lopez-de-Silanes, A. Shleifer, dan R. W. Vishny. 1999. Corporate 
ownership around the world. Journal of Finance 54 (2): 471-517.

La Porta, R., F. Lopez-de-Silanes, A. Shleifer, dan R. W. Vishny. 2000. Investor protection and corporate governance. Journal of Financial Economics 58 (12): 3-27.

Lennox, C. 1999. Audit quality and auditor size: An evaluation of reputation and deep pockets hypotheses. Journal of Business Finance \& Accounting 26 (7/8): 779-805.

Lin, J. Z., dan M. Liu. 2009. The impact of corporate governance on auditor choice: Evidence from China. Journal of International Accounting, Auditing, and Taxtation 18 (1): 44-59.

O'Sulliva, N., 2000. The impact of board composition and ownership on audit quality: evidence from large UK companies. The British Accounting Review 32 (4): 397-414.

Sharma, V. D., D. S. Sharma, dan U. Ananthanarayanan. 2011. Client importance and earnings management: The moderating role of audit committees.
AUDITING: A Journal of Practice \& Theory 30 (3):125-156.

Shleifer, A., dan R. W. Vishny. 1986. Large shareholders and corporate control. The Journal of Political Economy 94 (3): 461-488.

Simunic, D. A., dan M. T. Stein. 1996. The impact ligitation riskon audit pricing: A review of the economics and the evidence. Auditing: Journal of Practice and Theory 15: 119-134.

Soedibyo, A. N. 2010. Peran nutrient information dan information consciousness dalam memoderasi hubungan antara job satisfaction dan turnover intention di Kantor Akuntan Publik. Unpublished Thesis, Program Magister Akuntansi Unversitas Indonesia.

Titman, S., dan B. Trueman. 1986. Information quality and the valuation of new issues. Journal of Accounting and Economics 8 (2): 159-172.

Willenborg, M. 1999. Empirical analysis of the economic demand for auditing in the initial public offerings market. Journal of Accounting Research 37 (1): 225-239.

\footnotetext{
${ }^{1}$ Hak kendali adalah hak suara untuk ikut serta dalam menentukan kebijakan penting

${ }^{2}$ Hak arus kas adalah klaim keuangan pemegang saham terhadap perusahaan

${ }^{3}$ Penurunan cost of capital terjadi ketika perusahaan mampu mendapatkan pinjaman (debt) dengan bunga yang lebih rendah dan ketika perusahaan mampu menjual saham dengan harga yang lebih mahal (Lin \& Liu, 2009)

${ }^{4}$ Hak kendali (control right) terdiri dari hak kendali langsung dan hak kendali tidak langsung. Hak kendali langsung adalah prosentase saham yang dimiliki oleh pemegang saham pengendali atas nama dirinya sendiri. Sementara hak kendali tidak langsung adalah penjumlahan atas hak kendali minimum dalam setiap rantai (La Porta et al, 1999).
} 